\title{
Ecological and Socio-Economic Importance of Indigenous Multipurpose Fodder Trees in Three Districts of Wolayta Zone, Southern Ethiopia
}

\author{
Takele Geta ${ }^{1,2^{*}}$, Lisanework Nigatu ${ }^{2}$ and Getachew Animut ${ }^{3}$ \\ ${ }^{1}$ Jigjiga University, P.O. Box 1020, Jigjiga, Ethiopia \\ ${ }^{2}$ Haramaya University, P.O. Box 138, Dire Dawa, Ethiopia \\ "Corresponding author: Takele Geta, Jigjiga University, P.O. Box 1020, Jigjiga, Ethiopia, Tel: 251925171982; E-mail: takeleg@gmail.com
}

Rec date: March 07, 2014; Acc date: June 12, 2014; Pub date: June 21, 2014

Copyright: (c) 2014 Geta et al. This is an open-access article distributed under the terms of the Creative Commons Attribution License, which permits unrestricted use, distribution, and reproduction in any medium, provided the original author and source are credited.

\begin{abstract}
Indigenous multipurpose fodder trees have important social, economic and ecological functions such as controlling erosion, contribute to human quality of life, provide sinks for carbon dioxide and methane at the interface between the decaying fallen leaves and the soil and are a source of biodiversity. In this study, we assess ecological and socio-economic importance of the indigenous multi-purpose fodder tree (MPFT) species in three districts of Wolayta Zone of Southern Nations Nationalities and Peoples Regional State. Structured questionnaires' were distributed to 270 respondents. The results indicated that indigenous MPFTs have important social, economic and ecological functions, such as food supply, shade, traditional medicines, and the preservation of milk, animal nutrition, social values and household income. For animal feeding, vegetation was cut, especially leaves, young tips, twigs and fruits. About $70 \%$ of the respondents were unaware of the benefits of the MPFTs. It is concluded that the indigenous MPFT have a strong social and ecological value, and a source of income supplementation.
\end{abstract}

Keywords Ecological; Social; Economic; Resources; Indigenous; Fodder tree; Traditional medicinal value

\section{Introduction}

The social, economic and ecological functions of indigenous multipurpose fodder tree resources are important for human quality of life, national economic support, household income and environmental protection [1]. Multipurpose fodder trees (MPFTs) are woody perennials grown for several functions (for example, shelter, shade, land sustainability) within the land-use system [2]. Multipurpose fodder trees are also important for erosion control, carbon dioxide and methane sinks and biodiversity $[3,4]$.

Indigenous MPFTs are grown as part of the farming system. Although most of the indigenous fodder tree species are not primarily grown for fodder but for other purposes, they are readily available for livestock feed.

Several studies on multi-purpose fodder trees (MPFTs) have been conducted in different parts of Ethiopia [5-10]. However, most deal with introduced or exotic fodder tree species and very little information is available on the socio-economic values of indigenous MPFTs, despite their importance as resources. It is, therefore, imperative to characterize and assess the socio economic values of the indigenous MPFTs in order to design management options for long term sustainable use in Wolayta zone and in areas with similar agroecologies. Therefore, the objective of this study was to assess ecological and socio-economic importance of the indigenous multipurpose tree species in the study districts.

\section{Materials and Methods}

\section{Study location}

The study was conducted in three districts of Wolayta Zone, Southern Nation Nationalities Regional State (Figures 1 and 2). The three districts were selected based on the potential of livestock production and were in different altitudinal ranges. The districts were Soddo Zuria (highland), Damot Woyde (mid altitude) and Humbo district (lowland) and were located at $330 \mathrm{~km}, 356 \mathrm{~km}$ and $347 \mathrm{~km}$ South of capital city, Addis Ababa, and at altitude between of 1950-2400, 1400-1750 and 750-1100 meters above sea level, respectively. Throughout this region, there are 8 to 10 months of variable rainfall and the main rainy season extends from May to September, with a shorter rainy season from February to April [11].

The Sodo Zuria is located approximately at $6050^{\prime} \mathrm{N}-7 \mathrm{o} 53^{\prime} \mathrm{N}$ and 37036 'E-37o53'E, Damot Woyde is located approximately at $6043^{\prime} \mathrm{N}-7033^{\prime} \mathrm{N}$ and $37 \mathrm{o} 28^{\prime} \mathrm{E}-37 \mathrm{o} 43^{\prime} \mathrm{E}$ and Humbo districts is located approximately at $6034^{\prime} \mathrm{N}$ and $37043^{\prime} \mathrm{E}$ latitude and longitude, respectively. The soil types of the three districts were vertisoil and nitosoil. The annual maximum rainfall of the study districts are 1300 $\mathrm{mm}, 1100 \mathrm{~mm}$ and $900 \mathrm{~mm}$ and the minimum rainfall are $1150 \mathrm{~mm}$, $1000 \mathrm{~mm}$, and $650 \mathrm{~mm}$ for Sodo Zuria, Damote Woyde and Humbo districts, respectively. Temperature range $13-260 \mathrm{C}, 17-24 \mathrm{oC}$ and 18-30oC for Sodo Zuria, Damote Woyde and Humbo districts, respectively [12].

The agricultural production and land use systems are dominantly mixed crop-livestock farming system. Crops and livestock husbandry are common practices in the three districts where an extensive livestock production mainly depend on free grazing and cut and carry (in- door/out-door stall) feeding systems. Pastures and hay from hedgerows, pastureland, crop residues and crop left over on farm land, agro-industrial by-products like furishika and furishikelo, false banana 
Citation: Takele G, Nigatu L, Getachew A (2014) Ecological and Socio-Economic Importance of Indigenous Multipurpose Fodder Trees in Three Districts of Wolayta Zone, Southern Ethiopia. J Biodivers Endanger Species 2: 136. doi:10.4172/2332-2543.1000136

Page 2 of 5

or enset and its by-products and browses are all feed resources in the study districts.

Subsistence production and rain fed agriculture are the main livelihood activities. The main economic sources for the districts were sale from crops, animals, animal products and off-farm activities like working around town, construction labourers, merchants and employed in government and non-governmental organizations (NGOs).

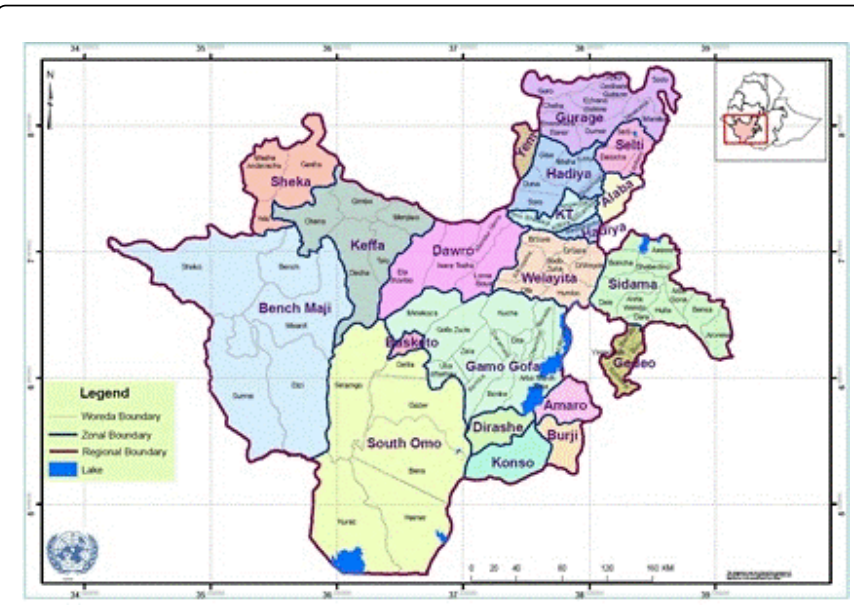

Figure 1: Map of Southern Nations and Nationalities Regional state (source: UN)

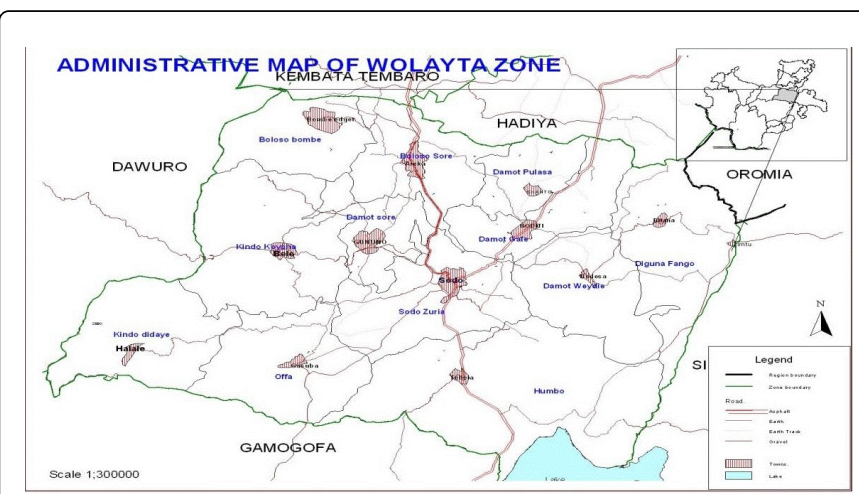

Figure 2: Map of Wolayta Zone (Source: Zonal finance and economy office)

\section{Socio-economic survey}

Nine kebeles ( 3 from each districts), and a total of 270 households (HHs) from the three districts were selected based on the availability of indigenous MPFTs for socio-economic values, and the utilization of these species for livestock feeding and livestock ownership. The HHs was used to collect the survey data. The socio economic survey was collected following the participatory rapid appraisal (PRA) procedure using questionnaire and interviews.

\section{Identification and selection of indigenous multipurpose trees}

Households were asked to identify and rank the different multipurpose trees (MPFTs) on the basis of their utilization as animal feed, fooder tree availability and other benefits. Based on their rank, the top five MPFTs were selected to investigate their social, economic and ecological importance. Data collected included $\mathrm{HH}$ structure, income source for households, uses and socio-economic importance of multipurpose fodder trees, utilization practices for multipurpose fodder trees, perceptions of people towards fodder trees, attitude and skill of utilization, their knowledge gap toward indigenous multipurpose fodder trees for multiple use strategies.

\section{Statistical analysis}

The socio economic survey data was analysed using descriptive statistics by the SPSS software [13].

\section{Results}

\section{Identification and selection of indigenous multipurpose trees}

The respondents include people of all age groups using indigenous multipurpose fodder trees for different socio economic uses. Respondents revealed that the indigenous MPFTs were used it ameliorate food scarcity during the annual dry season. Based on the interview result, 28 indigenous MPFT species were identified in the area (Table 1). The MPFT foliages were good for fodder to reduce the food shortage and contribute to better animal productivity.

\begin{tabular}{|c|c|c|}
\hline Scientific name & Family Name & $\begin{array}{ll}\text { Local } & \text { Name } \\
\text { (Wolaytegna) } & \end{array}$ \\
\hline Acanthus pubescens (Oliv.) Engl. & Acanthaceae & Ohaa \\
\hline Buddleja polystachya Fresen & Loganiaceae & Shinkaa \\
\hline Celtis africana Burm. $f$ & Ulmaceae & Shuwaa \\
\hline Clausena anisata (Willd.) Benth. & Rutaceae & Ciqottiyaa \\
\hline Clutia lanceolata Forssk & $\begin{array}{l}\text { Euphorbiacea } \\
\text { e }\end{array}$ & Higishsha meruwaa \\
\hline Combretum molle R. Br. ex G. Don & $\begin{array}{l}\text { Combretacea } \\
\text { e }\end{array}$ & Sobbuwaa \\
\hline Erythrina brucei Schwein & Fabaceae & Bortuwaa \\
\hline $\begin{array}{l}\text { Grewia ferruginea Hochst.exA. } \\
\text { Rich. }\end{array}$ & Tiliaceae & Gumariyaa \\
\hline Ficus thonningii Blume & Moraceae & Dambiyaa \\
\hline Maytenus serrata (A.Rich.) Wilczek & $\begin{array}{l}\text { Celasteracea } \\
\mathrm{e}\end{array}$ & Gershshuwaa \\
\hline Maytenus sp. & Celestraceae & Xuxuwaa \\
\hline Maesa lanceolata Forssk. & Myrsinaceae & Gerrgecuwaa \\
\hline Millettia ferruginea (Hochst.) Bak. & Fabaceae & Botta zagiyaa \\
\hline Nuxia congesta R.Br. ex Fresen & Loganiaceae & Woraa shinkaa \\
\hline Olea europaea L.subsp. & & \\
\hline
\end{tabular}




\begin{tabular}{|l|l|l|}
\hline Cuspidate (WalL.ex G.Don) Cif & Oleacea & Wogera \\
\hline Pavetta oliveriana & Rubiaceae & Kana miqiyaa \\
\hline Rhus glutinosa & $\begin{array}{l}\text { Anacardiacea } \\
\text { e }\end{array}$ & Xamuwaa \\
\hline Rhus vulgaris Meikle & $\begin{array}{l}\text { Anacardiacea } \\
\text { e }\end{array}$ & Micekkuwaa \\
\hline Rytigynia neglecta (Hiem) Robyns & Rubiaceae & Miqiyaa \\
\hline Vangueria apiculata K. Schum. & Rubiaceae & Jijuwaa \\
\hline $\begin{array}{l}\text { Vernonia adoensis Sch. Bip. ex } \\
\text { Walp. }\end{array}$ & Asteraceae & Kanaa Hamakka \\
\hline Vernonia amygdalina Del. & Asteraceae & Garaa \\
\hline Vernonia sp. & Asteraceae & Yemenuwaa \\
\hline Schrebera alata (Hochst.) Welw. & Oleaceae & Qaraa \\
\hline Terminalia schimperiana Hochst. & $\begin{array}{l}\text { Combretacea } \\
\text { e }\end{array}$ & Ambiyaa \\
\hline
\end{tabular}

Table 1: List of identified multipurpose trees indigenous species commonly found collected from three study districts.

\section{Social and economic values of indigenous fodder trees}

About $74 \%$ of the respondents of the three districts noted that the identified indigenous MPFTs are used for shade for animals and humans, while about $18 \%$ of the respondents said that the fodder trees are used to treat animal diseases. MPFTs also provide social acceptance for the owners in social meetings by serving as a shaded meeting place. In some districts, farmers use trees and shrubs to preserve livestock products such as milk. Wood from some species of trees was used to smoke milk, which increased both the preservation and flavour of the milk.

\begin{tabular}{|l|l|l|l|}
\hline Scientific name & \% of respondents (\%) & Rank & Form of sale ${ }_{-}^{*}$ \\
\hline C.molle & 73.3 & 11 & 2 \\
\hline C.africana & 91.8 & 1 & 1,2 \\
\hline D.abyssinica & 65.5 & 5 & 2 \\
\hline E.cymosa. & 76.3 & 6 & 2 \\
\hline E.brucei & 82.6 & 2 & 1,2 \\
\hline F. thonningii & 68.5 & 7 & 1,2 \\
\hline M. ferruginea & 78.2 & 8 & 1,2 \\
\hline O.cuspidata & 80.7 & 3 & 2 \\
\hline V.amygdalina & 70 & 4 & 2 \\
\hline T.schimperiana & 79.6 & 9 & 1,2 \\
\hline
\end{tabular}

Table 2: List of identified marketable indigenous fodder trees of the three districts $\left({ }^{\star} 1=\right.$ timber; $2=$ whole sale $)$
In addition, sale of wood, fruits and other tree products bring economic benefits for local people (Table 2) and provide an opportunity to enhance household incomes in the study districts. The analysis result showed that $93.7 \%$ of respondents in the three districts use MPFTs as an income source. Income is generated from sale of whole trees or after processing. Timber production (e.g., C. africana) is particularly important to resource poor farmers for basic income.

The fruit of O. cuspidata is also used as raw materials for Zenith Cosmetics manufacturing industry in Addis Abeba, Ethiopia is known for production of Oliva Hair oil which is extra rich for dry hair.

\section{Utilization of indigenous multipurpose fodder trees for animal production}

Indigenous MPFTs are used as supplementary feed for animal production, some bing more valuable for this function than others, especially during the dry season, this believed to be important for livestock health and milk production. There are also some MPFTs that serve as medicinal value to treat certain ailments (Table 3). Data from this study revealed that out of 28 identified indigenous MPFTs, $23 \%$ were used for feed all year round, $27 \%$ were used from September to March, $10 \%$ were used from September to February, $17 \%$ were used from November to March, 13\% were used from November to April, $3 \%$ were used from October to February, and 7\% from November to February in three districts.

Utilization of indigenous MPFT species by animals depends on availability of fodder trees, selection by the animals, their effects after consumption and purposes to be obtained after consumption. Animals preferred some trees more than others. Among identified indigenous MPFTs, $33 \%$ were consumed by cattle, sheep and goats, $17 \%$ by cattle and goats, $13 \%$ by cattle and sheep, $23 \%$ by cattle only, and $13 \%$ were consumed by goats only. Regarding the benefit of indigenous MPFTs for animal production, about $17 \%$ were for both maintenance and to improve milk production, while $7 \%$ was for maintenance, improvement of milk production and traditional medicines, $13 \%$ was for both maintenance and traditional medicines, $43 \%$ for only maintenance, $17 \%$ for both maintenance and growth, and about $3 \%$ were for maintenance, growth and to improve milk production.

\section{Perception of Farmers toward Indigenous Multipurpose Fodder Trees}

According to respondents of the study districts, indigenous MPFT species (Appendix Table 1) are believed to be nutritious and are important for livestock production in promoting not animal health but also growth and milk production. Butter-fat production in lactating animals and improvements in animal health were also mentioned by the respondents as good attributes of MPFTs. Indigenous MPFT species such as V. amygdalina and E. cymosa are believed to have traditional medicinal value and the leaves, tips and pods of such plants are ground mixed with Coffee arabica leaves and boiled and used as medicine to treat certain ailments. 
Citation: Takele G, Nigatu L, Getachew A (2014) Ecological and Socio-Economic Importance of Indigenous Multipurpose Fodder Trees in Three Districts of Wolayta Zone, Southern Ethiopia. J Biodivers Endanger Species 2: 136. doi:10.4172/2332-2543.1000136

Page 4 of 5

\begin{tabular}{|c|c|c|c|}
\hline E. brucei & All year round & Cattle, goat, sheep & Maintenance \& milk production \\
\hline V. amygdalina & All year round & Cattle, sheep goat & Maintenance, Milk production \& Traditional medicine \\
\hline E. cymosa & All year round & Cattle, Goat, Sheep & Maintenance, Milk production \& Traditional medicine \\
\hline C. africana & Sept. to Mar. & Cattle & Maintenance \\
\hline D. abyssinica. & All year round & Cattle, Goat, sheep & Maintenance \& Growth \\
\hline B. polystachya & Sept. to Mar. & Cattle, Goat, sheep & Maintenance, Milk production \\
\hline G. ferruginea & Sep. to Feb & Goat, Cattle, Sheep & Maintenance \& milk production \\
\hline O. cuspidate & Nov. to Apr. & Cattle, sheep \& goat & Maintenance \\
\hline A. pubescens & Nov. to Mar. & Goat & Maintenance \\
\hline F. thonningii & Sept. to Mar. & Cattle, sheep \& goat & Maintenance \& traditional medicine \\
\hline T. schimperiana. & Sept. to Mar. & Cattle, sheep \& goat & Maintenance \\
\hline R. vulgaris & All year round & Cattle \& Goat & Maintenance, \& milk production \\
\hline C. lanceolata & Sept. to Feb. & Cattle & Maintenance \& traditional medicine \\
\hline Vernonia sp. & Nov. to Apr. & Cattle, sheep & Maintenance \& traditional medicine \\
\hline S. alata & Oct. to Feb & Cattle, sheep & Maintenance \& Growth \\
\hline M. serrata & Nov. to Feb. & Cattle & Maintenance \\
\hline V. adoensis & Nov. to Apr. & Cattle & Maintenance \& Traditional medicine \\
\hline Celtis Africana & Sept. to Mar. & Cattle, sheep & Maintenance, Growth \& Milk production \\
\hline M. ferruginea & Nov. to Mar. & Cattle, sheep & Maintenance \\
\hline R. neglecta & Nov. to Apr. & Goat, Cattle & Maintenance \\
\hline C. anisata & Sept. to Mar. & Cattle, Goat & Maintenance, Growth \\
\hline V. apiculata & All year round & Goat & Maintenance \& Growth \\
\hline Maytenus sp. & All year round & Goat & Maintenance, Growth \\
\hline N. congesta & Sept. to Mar. & Cattle & Maintenance, Milk production \\
\hline M. lanceolata & Nov. to Mar. & Cattle, Goat & Maintenance, Growth \\
\hline R. glutinosa & Sept. to Feb. & Cattle & Maintenance \\
\hline P. oliveriana & Nov. to Feb. & Goat, Cattle & Maintenance \\
\hline C. molle & Nov. to Mar. & Cattle & Maintenance \\
\hline
\end{tabular}

Table 3: Utilization of indigenous multipurpose trees in the study districts

\section{Discussion}

Indigenous multipurpose fodder tree resources can increase food supplies to supplement poor quality roughages, as the MPFTs are rich in $\mathrm{CP}$, minerals and energy and can maintain their feeding value for extended period of time due to their deep root system [14-16]. This is supported by the findings of Komwihangilo et al. [17]. About $21.4 \%$ of identified indigenous MPFTs were used as honey bee forage. For example, the farmers use $O$. cuspidata trees leaves to smoke their traditional bee hives, thus attracting wild and foraging bees with its good smell (Appendix Table 2).
According to Abebe et al. [9] indigenous multipurpose trees provide many benefits including food, drink fruits, fuel wood, construction of hedges (fences), charcoal, furniture, resins or dyes, domestic uses or tools, honey from bees and also agro-ecological sustainability such as soil fertility, land improvement, erosion control and environmental air or atmosphere balance. They also serve as a storage material for grain (e.g. E. brucei, O. cuspidata). These social and livelihood benefits reinforce the importance of MPFTs in multiple use strategies. The research conducted in Southern part of Ethiopia [18] revealed that the sale of wild plants as fodder supplements contributes to farmer income sources. 
The respondents revealed that indigenous MPFTs are miracle tree used as meeting under the tree shade, providing service like boundary demarcation or barrier. About $67 \%, 60 \%$ and $63 \%$ of respondents' in Sodo Zuria, Damot Woyde and Humbo district respectively, noted that indigenous MPFTs were used as social and cultural values relating to spiritual, aesthetic, symbolic, historical and primarily with the interaction and relationships among people these may be wide ranging and include for example belonging, status, friendship and identity (Appendix Table 1). The leaves of the most MPFT species are good sources of green roughage if free from or contain minimal antinutritional factors.

The edible parts of indigenous fodder trees are mostly leaves and in some species young tips, twigs and stem, fruit pods are consumed by animals. The dominance of leaves as part of MPFT used as feed has also been reported in previous studies [9,19-21]. About $70 \%$ of the respondents appeared to have a knowledge gap about the advantage indigenous MPFTs. Even if indigenous multipurpose trees have multiple advantages in social and livelihood, economic and ecological values, they were generally ignored in reforesting. Only 30\% of respondents noted that of having some knowledge about the social and livelihood, economic and ecological values of indigenous MPFTs in three districts.

\section{Conclusion}

The indigenous MPFTs have strong social and economic value to the people in general. These plants are particularly important for income sources, a benefit to livestock and shade. The five MPFT species identified as important in the study area based on their abundance and utilization as social and economic value and animal feed are E. brucei, $V$. amygalina, E. cymosa, C. africana and $D$. abyssinica. Further studies may examine the status of these plants in other regions and also include more species for evaluation.

\section{Acknowledgement}

The support of the staff and farmers during the data collection period in the study districts is gratefully acknowledged. We also extend our sincere gratitude to the Ministry of Education (MOE) of Ethiopia, for funding this research, and the Wolayta Zone Agricultural office and all individuals for their continued provisions of facilities and enabling environment to conduct this research work.

\section{References}

1. Jebessa S (2003) Urbanization and Multi-Purpose Tree Resources in Ethiopia: A contingent Valuation Study.

2. Moges Y (2004) Recommeneded Agroforestry/Multipurpose trees for Borana lowlands, Middleland and their production techniques. Forestry Research Center, Dryland Forestry research project coordinator. Addis Ababa, Ethiopia.

3. Dzowela BH, Hove L, Maasdorp BV, Mafongoya PL (1997) Recent work on the establishment, production and utilization of multipurpose trees as a feed resource in Zimbabwe. Animal Feed Sci and Tech 69: 1-15.

4. Sorn S (2003) Increasing the germination capacity of tree cuttings; Retrieved on January 15, 2013, from MEKARN Mini-projects.
5. Yadessa A, Bekere D, Bekele T (2000) Growth performance of different multipurpose trees and shrub species at Bako, Western Oromiya.

6. Chibssa T, Didita M, Abera Y, Yadessa M (2006) Screening of multipurpose trees and shrub species for adaptation and growth performances at Sinan, South- Eastern Ethiopia. Sinan Agricultural research center, Robe- Bale, Ethiopia.

7. Tolera A (2007) Feed resource for producing export quality meat and livestock in Ethiopia. Examples of selected Woredas in Oromia and SSNP regional states. Ethiopia Sanitary \& Phytosanitary Standards and Livestock \& Meat Marketing Program (SPS- LMM) Texas Agricultural Experiment Station (TAES)/Texas A\&M University, Addis Ababa, Ethiopia.

8. Tadeg GA (2007) Evaluation of Tagasaste (Chamaecytisus Palmensis) as forage for ruminants. A PhD dissertation, Humboldt University, Berlin.

9. Mekoya A, Oosting SJ, Fernandez-Rivera S, Vander Zijpp AJ (2008) Multipurpose fodder trees in Ethiopia; Farmers' perception, constraints to adoption and effects of long- term supplementation on sheep performance. A PhD dissertation, Wageningen University, Wageningen, Netherlands. Accessed or retrieved on May 2010.

10. Haile Y, Tolemariam $\mathrm{T}$ (2008) The feed values of indigenous multipurpose trees for sheep in Ethiopia: The case of Vernonia amygdalina, Buddleja polystachya and Maesa lanceolata. Livestock Research for Rural Development 20: 3.

11. Kocho T, Geta E (2011) Agro-ecologic mapping of livestock system in smallholder crop-livestock mixed farming of Wolaita and Dawuro districts, Southern Ethiopia. Livestock research for rural development. LLRD Newsletter 22: 3.

12. Laekemariam F, Gidago G (2012) Response of Maize (Zea mays L.) to integrated fertilizer application in Wolaita, South Ethiopia. Advances in Life Science and Technology.

13. SPSS (Statistical Package for Social Science) for windows. 2003, Version 12.0, Chicago, IL: SPSS Inc.

14. Paterson R, Karanje G, Nraata O, Kariuki I, Roothaart R (1998) A review of tree fodder production and utilization with in smallholder agroforestry system in Kenya. Agroforestry systems 41: 181-199.

15. Upreti C, Shresta B (2006) Nutrient contents of feed and fodder in Nepal. Animal Nutrition division. Nepal Agricultural research Council, Kathmandu.

16. ZomerR, Trabucco A, Coe R, Place F (2009) Trees on Farm: 'Analysis of Global Extent and Geographical patterns of Agroforestry' ICRAF Working Paper. No.89. Nairobi: World Agroforestry Center.

17. Komwihangilo DM, Goromela EH, wire JMNB (1995) Indigenous knowledge in utilization of local trees and shrubs for sustainable livestock production in central Tanzania. Livestock Research for Rural Development 6: 3 .

18. Addiss G, Urga K, Dikasso D (2005) Ethnobotanical study of edible wild plants in some selected districts of Southern Ethiopia. Human Ecology 33: 83-118.

19. Melaku S (2002) Evaluation of selected multipurpose trees as feed supplements in tef (Eragrostis tef) straw based feeding of Menz sheep. PhD. Thesis, Humboldt University, Berlin Germany.

20. Alemayehu Mengistu (2006) Forage resources profile of Ethiopia. FAO forage resources profiles, FAO, Rome, Italy.

21. Ali M, Jamous R, Shafie J (2008) Traditional knowledge of wild edible plants used in Palestine (Northern West bank).A comparative study. Journal of Ethnobilogy and Ethno medicine 4: 1-13. 